\title{
KARAKTERISASI IKAN TERI (Stolephorus sp.) ASAP “KAHOLEO” YANG DIPRODUKSI DARI KOTA BAUBAU SULAWESI TENGGARA
}

\author{
Wa Ode Sriyani*, Moh. Nuh Ibrahim, Kobajashi T. Isamu \\ Jurusan Teknologi Hasil Perikanan Fakultas Perikanan dan Ilmu Kelautan Universitas Halu Oleo, \\ Jalan H.E.A Mokodompit Kampus Bumi Tridharma Anduonohu, Kendari 93232 Sulawesi Tenggara \\ Telepon +6282291421396 \\ *Korespondensi: waodesriyani@gmail.com \\ Diterima: 29 Januari 2019/Disetujui: 20 Maret 2019
}

Cara sitasi: Sriyani W, Ibrahim MN, Ishamu KT. 2019. Karakterisasi ikan teri (Stolephorus sp.) asap "Kaholeo" yang diproduksi dari Kota Baubau Sulawesi Tenggara. Jurnal Fish Protech. 2(1):131-139.

\begin{abstract}
Abstrak
Penelitian ini bertujuan untuk mengetahui komposisi kimia dan kandungan Polycyclic Aromatic Hidrocarbon (PAH) pada ikan teri asap "kaholeo" yang diproduksi dari Kota Baubau, Sulawesi Tenggara. Sampel diambil dari tiga produsen di Kelurahan Waruruma, Kota Baubau. Penelitian ini menggunakan metode deskriptif untuk memberikan gambaran umum tentang data yang telah diperoleh dengan ulangan sebanyak 3 kali $(n=3)$. Parameter yang diamati yaitu uji organoleptik (warna, aroma, tekstur, dan rasa), uji kimia (kadar air, kadar protein, kadar lemak, dan kadar abu) serta uji PAH. Hasil dari penelitian ini menunjukkan bahwa kualitas ikan teri asap terbaik terdapat pada produsen III dengan nilai warna 3,96, aroma 3,79, tekstur 3,32, dan rasa 3,69. Hasil uji kimia menunjukkan bahwa nilai kadar air tertinggi terdapat pada produsen III sebesar $7,72 \%$. Nilai kadar protein tertinggi terdapat pada produsen I sebesar 29,06\%. Nilai kadar lemak tertinggi terdapat pada produsen III sebesar 4,12\% dan nilai kadar abu tertinggi terdapat pada produsen I sebesar 0,12\%. Hasil uji kandungan PAH menunjukkan bahwa produsen I memiliki kandungan PAH tertinggi yaitu naphthalene $8,19 \mathrm{ppm}$, acenaphthene $8,55 \mathrm{ppm}$, phenanthrene 21,96 ppm, pyrene $22,59 \mathrm{ppm}$, benzo(a)anthracene 4,21 ppm, dan benzo(a)pyrene 12,98 ppm.
\end{abstract}

Kata kunci: Stolephorus sp., kaholeo, pengasapan, komposisi gizi

\section{CHARACTERIZATION OF SMOKED ANCHOVY (Stolephorus sp.) “KAHOLEO" PRODUCED FROM THE CITY OF BAUBAU, SOUTHEAST SULAWESI}

\begin{abstract}
This study aims to determine the chemical composition and content of Polycyclic Aromatic Hydrocarbon (PAH) in "Kaholeo" smoked anchovy produced from the City of Baubau, Southeast Sulawesi. Samples were taken from three producers in Waruruma village, Baubau city. This study use a descriptive method to provide a general description of the data that has been obtained by three times replication $(n=3)$. The parameters observed were organoleptic test (color, odor, texture, and taste), chemical test (moisture content, protein content, fat content, and ash content) and PAH test. The results of this study indicate that the best quality of smoked anchovy is found in producer III with a color value of 3,96, odor of 3,79, texture of 3,32, and flavor of 3,69.
\end{abstract}


The chemical test results showed that the highest moisture content was producer III at $7,72 \%$. The highest protein content value was producer I at $29,06 \%$. The highest value of fat content was producer III at $4,12 \%$ and the highest ash content was producer I at $0,12 \%$. The results of the PAH content showed that producer I had the highest PAH content, namely naphthalene 8,19 ppm, acenaphthene 8,5\% ppm, phenanthrene 21,96 ppm, pyrene $22,59 \mathrm{ppm}$, benzo(a)anthracene 4,21 ppm, and benzo(a)pyrene 12,98 ppm.

Key words: Stolephorus sp., kaholeo, fumigation, nutritional composition

\section{PENDAHULUAN}

Ikan merupakan salah satu hasil perikanan yang mudah mengalami kerusakan karena memiliki kadar air yang tinggi. Upaya untuk mencegah kerusakan tersebut, diperlukan usaha berupa pengolahan dan pengawetan baik secara tradisional maupun modern (Murniyati dan Sunarman, 2000). Berbagai macam cara pengawetan ikan telah dilakukan saat ini dengan tujuan mengurangi kadar air dalam tubuh ikan, sehingga tidak dapat memberikan kesempatan pada bakteri (mikroba) untuk hidup dan berkembang (Berhimpon et al., 2002). Salah satu metode pengawetan ikan yang sudah banyak digunakan adalah pengasapan (Ghazali et al., 2014).

Pengasapan merupakan suatu cara pengolahan atau pengawetan dengan memanfaatkan kombinasi perlakuan pengeringan dan pemberian senyawa kimia dari hasil pembakaran bahan bakar alami (Wibowo, 2000). Selain untuk mengawetkan ikan, pengasapan juga berfungsi untuk menambah citarasa dan warna pada makanan (Adawiyah, 2008). Pengawetan dapat berpengaruh baik oleh mutu maupun daya awet produk yang diasap mulai dari cara persiapan bahan, jenis bahan bakar yang digunakan, kelembaban, kecepatan pengasapan, dan suhu pengasapan (Saleh dan Sari, 2007).

Indonesia memiliki berbagai produk pengolahan ikan asap salah satunya adalah ikan kaholeo (istilah lokal) yang diproduksi dari Kota Baubau, Provinsi Sulawesi Tenggara. Ikan kaholeo merupakan produk olahan yang dihasilkan dari proses pengasapan dengan menggunakan ikan teri sebagai bahan baku. Produk olahan ini memiliki kekhasan atau keunikan dari segi bentuk, warna, aroma, tekstur dan rasa. Salah satu pusat pengolahan ikan teri asap di Kota Baubau terdapat di Kelurahan Waruruma. Industri pengolahan ikan teri asap di kelurahan ini merupakan suatu usaha kecil yang dikelola oleh masyarakat pesisir pantai. Produk ikan teri asap yang dihasilkan masih bersifat tradisional, karena masih menggunakan cara sederhana dalam teknik pengolahannya seperti penggunaan bahan bakar yang diperoleh dari sekitar lingkungan, jenis kayu maupun peralatan pengasapan.

Salah satu permasalahan yang dihadapi dalam proses pengasapan adalah belum diterapkan standar proses yang baku, sehingga kualitas produk ikan asap yang dihasilkan dapat berbeda-beda. Perbedaan tersebut dapat dipengaruhi oleh beberapa faktor diantaranya adalah jenis bahan bakar, volume asap, kadar air dan jenis alat pengasapan (Ratna et al., 2011). Lama waktu proses yang tidak seragam, jumlah bahan pengasap yang tidak seragam, suhu ruang pengasapan yang tidak seragam, serta kualitas bahan pengasap yang digunakan berbeda-beda merupakan beberapa permasalahan 
yang sering pula dijumpai dalam proses pengasapan (Palm et al., 2011).

Menurut Ghazali et al. (2014), pengasapan tradisional seringkali memberikan dampak negatif terhadap lingkungan, serta timbul kekhawatiran konsumen terhadap senyawa karsinogenik. Pengasapan tradisional dapat memberikan potensi resiko bahaya bagi kesehatan manusia terkait adanya kandungan Polycyclic Aromatic Hydrocarbon (PAH) yang dihasilkan melalui pengasapan langsung pada proses pirolisis kayu (Putri dan Diana, 2015). Senyawa Polycyclic Aromatic Hydrocarbon (PAH) jenis benzo(a)pyrene merupakan senyawa karsinogenik penyebab kanker yang terdapat dalam produk asap (Guillen, 2000). Namun kenyataannya hasil produk tetap digemari oleh masyarakat (Swastawati et al., 2013).

Berdasarkan uraian di atas, maka perlu dilakukan suatu penelitian tentang karakterisasi ikan teri (Stolephorus sp.) asap "kaholeo" yang diproduksi dari Kota Baubau, Sulawesi Tenggara.

\section{BAHAN DAN METODE}

\section{Bahan dan Alat}

Bahan yang digunakan pada penelitian ini adalah ikan teri asap, aluminium foil, kertas label, kertas saring, $\mathrm{NaOH}, \mathrm{HCl}, \mathrm{H}_{2} \mathrm{SO}_{4}$, aquades, pelarut heksan, gas Nitrogen, diethyl ether, asam borat, bromcresol green, metil merah dan dichloromethane.

Alat-alat yang digunakan pada penelitian ini adalah piring, sendok, bulp, cawan petri, erlenmeyer, kompor listrik, mortal, tabung reaksi, timbangan analitik, pipet, rak tabung reaksi, porselin, tanur, buret, batang pengaduk, gelas beaker, gegep, desikator, labu ukur, oven, sokhlet, spatula, gunting, waterbath, plastik polyethilene dan GC SHIMADZU 2010.

\section{Metode Pengujian}

Sampel ikan teri asap diambil sebanyak $1 \mathrm{~kg}$ pada tiga produsen yang berbeda di Kota Baubau. Sampel yang dikumpulkan, dibungkus menggunakan plastik polyethylene (Wretling et al., 2010) dan disimpan dalam kemasan tertier (kotak plastik atau kardus) (Pratama, 2011) kemudian sampel dibawa ke laboratorium dan dilakukan analisis organoleptik, analisis kimia, dan analisis PAH.

Analisis organoleptik meliputi warna, aroma, tekstur dan rasa menggunakan metode uji tingkat kesukaan (hedonic scale) (Setyaningsih et al., 2010) dengan skala 1-5 (1=sangat tidak suka; $2=$ tidak suka; $3=$ agak suka, 4=suka; 5=sangat suka). Analisis kimia meliputi kadar air, kadar protein, kadar lemak dan kadar abu mengikuti metode AOAC (2005) serta analisis PAH (Polycyclic Aromatic Hydrocarbon) berdasarkan metode Laboratorium Penelitian dan Pengujian Terpadu (LPPT), Universitas Gajah Mada.

\section{Analisis Data}

Analisis data yang digunakan adalah analisis deskriptif untuk memberikan gambaran umum tentang data yang diperoleh dengan ulangan sebanyak 3 kali $(n=3)$. Hasil yang disajikan merupakan nilai rata-rata \pm standar deviasi (SD) (Lombongadil et al., 2013).

\section{HASIL DAN PEMBAHASAN}

Data hasil penelitian ikan teri asap yang diproduksi dari Kota Baubau, Sulawesi Tenggara dapat dilihat pada Tabel berikut. 
Tabel 1. Rekapitulasi hasil organoleptik ikan teri asap yang diproduksi dari Kota Baubau, Sulawesi Tenggara

\begin{tabular}{ccccc}
\hline Produsen & Warna \pm SD & Aroma \pm SD & Tekstur \pm SD & Rasa \pm SD \\
\hline I & $3,12 \pm 0,25$ & $3,48 \pm 0,07$ & $3,26 \pm 0,10$ & $3,46 \pm 0,22$ \\
II & $3,54 \pm 0,02$ & $3,51 \pm 0,11$ & $3,28 \pm 0,13$ & $3,65 \pm 0,04$ \\
III & $3,96 \pm 0,06$ & $3,79 \pm 0,12$ & $3,32 \pm 0,02$ & $3,69 \pm 0,09$ \\
\hline
\end{tabular}

\section{Uji Organoleptik}

\section{Warna}

Berdasarkan data pada Tabel 1 menunjukkan bahwa hasil penilaian uji organoleptik warna yang dihasilkan dari ikan teri asap memiliki nilai yang berbeda dari masing-masing produsen. Nilai warna tertinggi terdapat pada produsen III yaitu 3,9 dan terendah pada produsen I yaitu 3,12. Perbedaan warna pada ikan teri asap diduga disebabkan oleh lama pengasapan. Berdasarkan hasil pengamatan yang dilakukan selama penelitian, diketahui produsen III melakukan proses pengasapan selama 3 jam, produsen II selama 4 jam dan produsen I selama 6 jam. Menurut Mardiana et al. (2014), lama waktu pengasapan memberikan pengaruh terhadap penerimaan warna ikan asap. Karakteristik warna ikan sembilang asap perlakuan 3 jam dinilai sangat pas dengan warna coklat khas ikan asap.

\section{Aroma}

Berdasarkan data Tabel 1 menunjukkan bahwa nilai aroma tertinggi terdapat pada produsen III yaitu 3,79 dan terendah pada produsen I yaitu 3,48. Nilai aroma ikan teri asap berbeda untuk setiap produsen. Hal ini diduga disebabkan oleh ruang pengasapan yang digunakan. Berdasarkan hasil pengamatan yang dilakukan selama penelitian, diketahui produsen III menggunakan ruang pengasapan tertutup sehingga asap lebih banyak terkonsentrasi pada ikan yang diasapi. Menurut Dotulong dan
Montolalu (2018) menyatakan bahwa ikan yang diasapi pada rumah pengasapan tertutup menghasilkan aroma yang tinggi disebabkan karena panas dan asap lebih banyak terkonsentrasi melewati ikan yang sedang diasapi dibandingkan dengan ruang pengasapan terbuka, dimana panas dan asap tersebut menyebar dan tidak maksimal melewati ikan yang sedang diasapi karena ditiup angin.

\section{Tekstur}

Berdasarkan data Tabel 1 menunjukkan bahwa nilai tekstur tertinggi terdapat pada produsen III yaitu 3,32 dan terendah pada produsen I yaitu 3,26. Perbedaan nilai tekstur pada ikan teri asap yang diperoleh dari tiga produsen tersebut diduga dipengaruhi oleh lama pengasapan. Hal ini sesuai dengan pernyataan Sumartini et al. (2014) bahwa lama pengasapan menyebabkan perbedaan terhadap nilai tekstur ikan asap, dimana semakin lama ikan mengalami proses pengasapan maka tekstur yang dihasilkan akan semakin liat dan keras, sehingga tekstur tersebut kurang disukai panelis.

\section{Rasa}

Berdasarkan data Tabel 1 menunjukkan bahwa nilai rasa ikan teri asap tertinggi terdapat pada produsen III yaitu 3,69 dan terendah pada produsen I yaitu 3,46. Perbedaan nilai rasa pada ikan teri asap dari ketiga produsen tersebut diduga dipengaruhi oleh banyak sedikitnya asap yang menempel pada daging ikan yang diasapi. Menurut 
Lombongadil et al. (2013), semakin banyak asap yang diserap oleh tubuh ikan akan mempengaruhi rasa yang terdapat pada ikan asap tersebut. Isamu et al. (2012) menjelaskan bahwa perbedaan jumlah asap yang menempel pada ikan akibat lama waktu pengasapan dan banyaknya bahan pengasap yang digunakan akan menyebabkan bertambahnya komponen asap yang menempel pada ikan, sehingga warna, rasa dan aroma yang dihasilkan juga akan berbeda dari tiap produsen. Senyawa fenol dan karbonil berperan untuk memberikan rasa pada ikan asap (Martinez et al., 2007).

Tabel 2. Data Hasil Penelitian Uji Kimia Ikan Teri Asap yang Diproduksi dari Kota Baubau, Sulawesi Tenggara

\begin{tabular}{ccccc}
\hline Produsen & $\begin{array}{c}\text { Kadar air } \\
(\%) \pm \mathrm{SD}\end{array}$ & $\begin{array}{c}\text { Kadar protein } \\
(\%) \pm \mathrm{SD}\end{array}$ & $\begin{array}{c}\text { Kadar lemak }(\%) \pm \\
\text { SD }\end{array}$ & $\begin{array}{c}\text { Kadar abu } \\
(\%) \pm \mathrm{SD}\end{array}$ \\
\hline I & $6,34 \pm 0,99$ & $29,06 \pm 1,80$ & $3,18 \pm 0,09$ & $0,12 \pm 0,01$ \\
II & $6,41 \pm 0,19$ & $28,19 \pm 1,22$ & $3,58 \pm 0,13$ & $0,10 \pm 0,01$ \\
III & $7,72 \pm 0,43$ & $24,88 \pm 1,27$ & $4,12 \pm 0,04$ & $0,11 \pm 0$ \\
\hline
\end{tabular}

Tabel 3. Data hasil penelitian PAH pada ikan teri asap yang diproduksi dari Kota Baubau, Sulawesi Tenggara

\begin{tabular}{llccc}
\hline \multirow{2}{*}{ No } & \multicolumn{2}{c}{ Parameter Uji } & \multicolumn{3}{c}{ Produsen } \\
\cline { 3 - 5 } & & I & II & III \\
\hline 1 & Naphthalene $(\mathrm{ppm})$ & 8,19 & 0,43 & 2,12 \\
2 & Acenaphthene $(\mathrm{ppm})$ & 8,55 & 5,30 & 6,17 \\
3 & Phenanthrene $(\mathrm{ppm})$ & 21,96 & 2,31 & 1,40 \\
4 & Pyrene $(\mathrm{ppm})$ & 22,59 & 5,66 & 1,84 \\
5 & Benzo $(a$ )anthracene $(\mathrm{ppm})$ & 4,21 & 1,70 & 1,77 \\
6 & Benzo $(a)$ pyrene $(\mathrm{ppm})$ & 12,98 & 10,87 & 9,20 \\
\hline
\end{tabular}

\section{Uji Kimia}

Kadar Air

Tabel 2 menunjukkan bahwa nilai kadar air tertinggi terdapat pada produsen III yaitu $7,72 \%$, kemudian pada produsen II yaitu $6,41 \%$ dan terendah pada produsen I yaitu $6,34 \%$. Kadar air ikan teri asap masing-masing produsen memiliki nilai yang berbedabeda. Hal ini diduga disebabkan proses pengolahan tiap produsen berbeda. Perbedaan tersebut diantaranya adalah lama waktu pengasapan, banyaknya bahan pengasap yang digunakan, ruang pengasapan serta ukuran kalase. Dari hasil pengamatan yang dilakukan selama penelitian, produsen I diketahui melakukan proses pengasapan selama 6 jam dan membutuhkan bahan bakar sebanyak 92 buah, sedangkan produsen II selama 4 jam dan membutuhkan bahan bakar sebanyak 80 buah serta produsen III selama 3 jam dan membutuhkan bahan bakar sebanyak 75 buah. Menurut Isamu et al. (2012), semakin lama waktu pengasapan dan makin banyak jumlah bahan pengasap yang digunakan akan meningkatkan suhu ruang pengasapan. Hal ini kemudian akan berpengaruh pada pengurangan kadar air produk akibat panas yang ditimbulkan. Sulfiani et al. (2017) menyatakan bahwa semakin lama pengasapan maka kadar air akan 
menurun. Hal ini disebabkan kadar air bebas yang terkandung pada ikan asap mengalami penguapan sejalan dengan semakin lama pengasapan.

\section{Kadar Protein}

Tabel 2 menunjukkan bahwa produsen yang memiliki kadar protein tertinggi adalah produsen I yaitu $29,06 \%$, kemudian produsen II yaitu $28,19 \%$ dan produsen III yaitu $24,88 \%$. Rendahnya kandungan protein pada produsen III diduga dipengaruhi oleh kondisi pengasapan tertutup yang digunakan. Hal ini sesuai dengan pernyataan Wahyuni (1999) bahwa pada pengasapan ikan dengan kondisi yang tertutup, faktor lingkungan misalnya faktor angin kurang berpengaruh sehingga konsentrasi asap dan panas pada tempat pengasapan lebih banyak, yang selanjutnya akan berpengaruh terhadap kadar protein pada ikan yang diasap. Swastawati et al. (2012) menjelaskan bahwa perubahan nilai protein ikan disebabkan oleh adanya proses pengolahan terutama menggunakan panas. Kadar protein dapat menurun karena adanya proses pengolahan dengan terjadinya denaturasi protein selama pemanasan.

\section{Kadar Lemak}

Tabel 2 menunjukkan bahwa kadar lemak ikan teri asap tertinggi terdapat pada produsen III yaitu $4,12 \%$, kemudian pada produsen II yaitu 3,58\% dan terendah pada produsen I yaitu $3,18 \%$. Rendahnya nilai kadar lemak pada produsen I diduga disebabkan oleh lama waktu pengasapan dan suhu pengasapan. Hal ini sesuai dengan pernyataan Swastawati et al. (2013) bahwa semakin tinggi suhu dan lama pengasapan menyebabkan penurunan nilai kadar lemak. Pemanasan pada suhu tinggi dalam proses pengasapan akan mempercepat gerakan-gerakan molekul lemak sehingga jarak antara molekul menjadi besar, dengan demikian akan memudahkan pengeluaran lemak dari bahan. Sumartini et al. (2014) menyatakan bahwa komponen lemak akan bereaksi dengan senyawa dalam komponen asap sehingga akibat efek lama pengasapan menyebabkan turunnya kadar lemak. Lama pengasapan dapat mempengaruhi komposisi nutrisi ikan terutama kadar lemaknya. Lemak merupakan komponen yang mudah menguap akibat kontak dengan asap panas, maka lemak yang terdapat dalam tubuh ikan akan meleleh dan keluar melapisi permukaan daging ikan.

\section{Kadar Abu}

Hasil uji kadar abu pada ikan asap yang diambil dari tiga produsen berbeda berkisar $0,10 \%$ sampai dengan $0,12 \%$. Berdasarkan data Tabel 2 dapat diketahui bahwa kadar abu ikan teri asap tertinggi pada produsen I yaitu $0,12 \%$, kemudian produsen III yaitu $0,11 \%$, sedangkan terendah pada produsen II yaitu $0,10 \%$. Rendahnya persentase kadar abu pada produsen II diduga dipengaruhi oleh penanganan sebelum sampel diasapkan. Dari hasil pengamatan yang dilakukan selama penelitian diketahui ikan pada produsen II dicuci terlebih dahulu dengan air bersih kemudian ikan ditiriskan dan sebelum ikan diletakkan pada wadah pengasapan ikan disimpan di ember yang telah berisi air. Hal ini diduga menyebabkan terlarutnya mineral yang terkandung dalam ikan. Hal ini sesuai dengan penelitian yang dilakukan oleh Fendjalang (2012) yang menyatakan bahwa penanganan sebelum sampel diasapi menyebabkan perbedaan nilai kadar abu. Sebelum ikan diasapi, ikan dicuci kemudian dilakukan perendaman. Hal ini menyebabkan mineral yang terkandung dalam ikan ikut terlarut 
dengan air. Menurut Sudarmadji (2003), kandungan mineral pada ikan asap diperoleh dari kandungan mineral yang terkandung dalam daging ikan. Kadar abu merupakan parameter nilai gizi suatu bahan bahan makanan yang dihasilkan dari zat anorganik yang terkandung dalam ikan. Kadar abu berhubungan dengan kandungan mineral suatu bahan.

\section{PAH (Polycyclic Aromatic Hydrocarbon)}

Senyawa PAH (Polycyclic Aromatic Hydrocarbon) merupakan senyawa karsinogenik yang umumnya terdapat diproduk yang menggunakan suhu tinggi, khususnya pada produk ikan asap. Proses pembakaran yang kurang sempurna terhadap senyawa organik dapat menghasilkan senyawa PAH (Murdani et al., 2016).

Ikan teri asap hasil dari proses pengasapan yang diproduksi dari Kota Baubau, Sulawesi Tenggara kemudian dianalisis kandungan senyawa PAHnya. Senyawa PAH yang diuji pada ikan teri asap antara lain naphthalene, acenaphthene, phenanthrene, pyrene, benzo(a)anthracene, dan benzo(a)pyrene. Berdasarkan hasil uji PAH yang disajikan pada Tabel 3 memberikan informasi bahwa produsen I mengandung senyawa PAH yang lebih tinggi dibandingkan dengan produsen II dan produsen III. Kandungan PAH produsen I yaitu naphthalene $8,19 \mathrm{ppm}$, acenaphthene 8,55 ppm, phenanthrene $21,96 \mathrm{ppm}$, pyrene 22,59 ppm, benzo(a)anthracene 4,21 ppm, dan benzo(a)pyrene 12,98 ppm. Kandungan PAH produsen II yaitu naphthalene 0,43 ppm, acenaphthene 5,30 ppm, phenanthrene 2,31 ppm, pyrene 5,66 ppm, benzo(a)anthracene 1,70 ppm, dan benzo(a)pyrene 10,87 ppm. Kandungan $\mathrm{PAH}$ produsen III yaitu naphthalene 2,12 ppm, acenaphthene 6,17 ppm, phenanthrene 1,40 ppm, pyrene 1,84 ppm, benzo(a)anthracene $1,77 \mathrm{ppm}$, dan benzo(a)pyrene 9,20 ppm.

Tingginya kandungan benzo(a)pyrene pada produsen I diduga dipengaruhi oleh kandungan lemak, lama waktudan suhu pengasapan. Lama pengasapan akan meningkatkan suhu pengasapan sehingga lemak yang meleleh akan menetes pada bahan bakar sehingga menghasilkan tingkat $\mathrm{PAH}$ yang siginifikan selama proses pengasapan langsung dengan ikan. Hal ini sesuai dengan pendapat Menichini dan Bocca (2003) yang menyatakan bahwa jumlah PAH yang terbentuk selama pengolahan tergantung pada kandungan lemak, waktu dan suhu pengolahan. Pembentukan dapat disebabkan akibat perubahan beberapa komponen makanan seperti trigliserida dan kolesterol. Lemak yang meleleh dan jatuh pada bahan bakar yang panas akan menyebabkan terjadinya pirolisis lemak yang dapat menghasilkan PAH yang menguap dan tersimpan pada permukaan makanan.

Habitat ikan teri segar yang secara alami telah terakumulasi oleh PAH dapat mempengaruhi kandungan PAH yang terdapat pada ikan teri asap. Habitat ikan teri yang berada di pesisir laut memungkinkan adanya pencemaran air yang berasal dari lingkungan misalnya asap dari penggunaan bahan bakar yang dihasilkan dari perahu nelayan. Menurut Effendi (2003) mengemukakan bahwa PAH digunakan pada bahan bakar kendaraan, oli, aspal dan bahan pengawet kayu. Keberadaan $\mathrm{PAH}$ di perairan juga disebabkan oleh sumber antropogenik (aktivitas manusia) berupa penggunaan bahan bakar seperti petroleum. Hung (2011) melaporkan tingginya kadar $\mathrm{PAH}$ berada didekat pantai/pesisir laut.

Teknik preparasi sampel juga mempengaruhi tingkat kandungan $\mathrm{PAH}$ 
ikan teri asap. Sampel yang dianalisis berasal dari ikan yang masih menggunakan kulit. Umumnya lapisan paling luar ikan asap terutama kulit mengandung $\mathrm{PAH}$ yang lebih tinggi. Heruwati (2002) menyatakan bahwa bagian luar ikan yang terkena asap, terutama kulit dapat mengandung $\mathrm{PAH}$ lima kali lebih banyak daripada bagian utama tubuh dari produk.

\section{KESIMPULAN}

Berdasarkan hasil dan pembahasan, maka dapat disimpulkan bahwa ikan teri (Stolephorus sp.) asap "kaholeo" yang diproduksi dari Kota Baubau, Sulawesi Tenggara memiliki komposisi organoleptik, komposisi kimia dan kandungan Polycyclic Aromatic Hidrocarbon (PAH) (benzo(a)pyrene) yang tidak sama.

\section{DAFTAR PUSTAKA}

Adawyah R. 2008. Pengolahan dan Pengawetan Ikan. Bumi Aksara. Jakarta.

AOAC. 2005. Official Methods of Analysis. 18th ed. Association of Official Analytical Chemists, Washington DC.

Berhimpon S, Dien H, Montolalu R. 2002. Processing and The Prospect of Katsuobushi (Ikan Kayu) of North Sulawesi, Indonesia: A Review. Fish Handling and Processing Laboratory. Faculty of Fisheries and Marine Science. Sam Ratulangi University. Manado.

Dotulong V, Montolalu LADY. 2018. Perbaikan Mutu Organoleptik Ikan Roa (Hemirhamphus Sp.) Asap Melalui Metode Pengasapan Ruang Tertutup. Jurnal Media Teknologi Hasil Perikanan. (6)1.
Effendi H. 2003. Telaah Kualitas Air Bagi Pengelolaan Sumberdaya Dan Lingkungan Perairan. Kanisius. Yogyakarta.

Fendjalang SNM. 2012. Analisis Kimia Ikan Tuna Asap Pada Beberapa Pasar Tradisional Di Tobelo, Kabupaten Halmahera Utara. Prosiding Seminar Nasional KSP2K II. 1(2):174-178.

Ghazali RR, Swastawati F, Romadhon. 2014. Analisa Tingkat Keamanan Ikan Manyung (Arius Thalassinus) Asap Yang Diolah Dengan Metode Pengasapan Berbeda. Jurnal Pengolahan dan Bioteknologi Hasil Perikanan 3(4): 31-38.

Guillen MD, Sopelana P, Partearroyo MA. 2000. Polycyclic Aromatic Hydrocarbons In Liquid Smoke Flavorings Obtained From Different Types Of Wood, Effect Of Storage In Polyethylene Flasks On Their Concentrations. J Agric Food Chem 48: 5083-6087.

Heruwati ES. 2002. Pengolahan Ikan Secara Tradisional: Prospek Dan Peluang Pengembangan. Jurnal Litbang Pertanian. 21:92-99.

Hung CC. 2011. Polycyclic Aromatic Hydrocarbons In Surface Sediments Of The East China Sea And Their Relationship With Carbonaceous Materials. Mar. Poll. Bull. 63: 464-470.

Isamu KT, Purnomo $\mathrm{H}$, Yuwono $\mathrm{S}$. 2012. Karakteristik Fisik, Kimia dan Organoleptik Ikan Cakalang (Katsuwonus pelamis) Asap di Kendari. Jurnal Teknologi Pertanian. 13(2): 105-110.

Lombongadil GP, Reo AR, Onibala, H. 2013. Studi Mutu Produk Ikan Japuh (Dussumieria acuta C.V.) 
Asap Kering Industri Rumah Tangga Di Desa Tumpaan Baru Kecamatan Tumpaan. Fakultas Perikanan Dan Ilmu Kelautan. Universitas Samratulangi. Sulawesi Utara. Manado. Jurnal Media Teknologi Hasil Perikanan. 1(2).

Mardiana N, Waluyo S, Ali M. 2014. Analisis Kualitas Ikan Sembilang (Paraplotosus albilabris) Asap di Kelompok Pengolahan Ikan Mina Mulya, Kecamatan Pasir Sakti Lampung Timur. Jurnal Teknik Pertanian Lampung 3(3): 283290.

Martinez O, Salmerón J, Guillén MD, Casas C. 2007. Sensorial and Physicochemical Characteristics Of Salmon (Salmo salar) Treated By Different Smoking Processes During Storage. Food Science and Technology International. 13: 477-484.

Menichini E, Bocca B. 2003. Polycyclic Aromatic Hydrocarbons. Di dalam: Caballero B, Trugo L, Finglas PM, editor. Encyclopedia of Food Sciences and Nutrition. 4616-4625.

Murdani H, Supriadi A, Lestari S. 2016. Kualitas Ikan Gabus (Channa striata) Asap yang Dibuat dengan Alat dan Sumber Asap yang Berbeda. FishtecH-Jurnal Teknologi Hasil Perikanan. 5(1): 52-60.

Murniyati AS, Sunarman. 2000. Pendinginan, Pembekuan dan Pengawetan Ikan. Kanisius. Yogyakarta.

Palm LMN, Deric C, Philip OY, Winston JQ, Mordecai AG, Albert D. 2011. Characterization of Polycyclic Aromatic Hydrocarbons (PAHs) Present In
Smoked Fish from Ghana. Advanced Journal of Food Science and Technology 3(5): 332-338.

Pratama RI. 2011. Karakteristik Flavor Beberapa Jenis Produk Ikan Asap Di Indonesia. Tesis. Institut Pertanian Bogor. Bogor.

Putri RE, Diana. 2015. Karakterisasi Asap Cair Dari Tempurung Kelapa Sebagai Pengganti Pengasapan Tradisional Pada Ikan Bilih (Mystacoleuseus padangensis). Agrica Ekstensia. 9 (2).

Ratna, Safridar, Yulinar. 2011. Variasi Jenis Bahan Bakar Pada Pengasapan Ikan Bandeng (Chanos-chanos forskal ) Menggunakan Alat Pengasapan Tipe Kabinet. Jurusan Teknik Pertanian, Universitas Syiah Kuala. Banda Aceh. Jurnal Ilmiah Pendidikan Biologi, Biologi Edukasi. 3(2).

Saleh M, Sari A. 2007. Kumpulan Hasil-Hasil Penelitian Pasca Panen Perikanan. Balai Besar Riset Pengolahan Produk dan Bioteknologi Kelautan dan Perikanan. Jakarta. 313 hal.

Setyaningsih D, Apriyantono A, Sari MP. 2010. Analisis Sensori untuk Industri Pangan dan Agro. IPB Press, Bogor.

Sudarmaji S, Hariyono B, Suhardi. 2003. Analisa Bahan Makanan dan Pertanian. Liberty. Yogyakarta. $171 \mathrm{hlm}$.

Sulfiani, Sukainah A, Mustarin A. 2017. Pengaruh Lama Dan Suhu Pengasapan Dengan Menggunakan Metode Pengasapan Panas Terhadap Mutu Ikan Lele Asap. Jurnal 
Pendidikan Teknologi Pertanian. 3: 93-101.

Sumartini, Swastawati F, Agustini TW. 2014. Analisis Asam Lemak Omega 3,6,9 Dan Kadar Fenol Ikan Bandeng (Chanos chanos Forsk) Asap Dengan Kombinasi Jarak Tungku Dan Lama Pengasapan. Jurnal Pengolahan dan Bioteknologi Hasil Perikanan. 3(1): 157-166.

Swastawati F, Susanto E, Cahyono B, Trilaksono WA. 2012. Sensory Evaluation and Chemical Characteristics of Smoked Stingray (Dasyatis blekeery) Processed by Using Two Different Liquid Smoke. International Journal of Bioscience, Biochemistry and Bioinformatics 2 (3): 212-216.

Swastawati F, Surti T, Agustini TW, Riyadi PH. 2013. Karakteristik Kualitas Ikan Asap yang Diproses Menggunakan Metode dan Jenis Ikan Berbeda. Jurnal Aplikasi Teknologi Pangan. 2(3): 126 132.

Wahyuni S. 1999. Pengaruh Pengolahan Tradisional terhadap Mutu dan Nilai Gizi Ikan Teri Asap. [Tesis]. Fakultas Teknologi Pertanian, Institut Pertanian Bogor. Bogor.

Wibowo S. 2000. Industri Pengasapan Ikan. Penebar Swadaya. Jakarta.

Wretling S, Eriksson A, Eskhult GA, Larsson B. 2010. Polycyclic Aromatic Hydrocarbons (PAHs) in Swedish Smoked Meat and Fish. Journal of Food Composition and Analysis 23: 264-272. 